\title{
Effect of Enhydra fluctuans on Kidney Function in Alloxan-induced Diabetic Rats
}

\author{
Rina Delfita ${ }^{1,2 *} \mathbb{D}$, Dahelmi Dahelmi ${ }^{2}$, Djong Tjong $^{2}$ (D) S Suhatri Suhatri $^{3}$ (iD \\ ${ }^{1}$ Department of Biology Education, Faculty of Tarbiyah and Teacher Training, IAIN Batusangkar, West Sumatera, Indonesia; \\ ${ }^{2}$ Department of Biology, Faculty of Mathematics and Natural Science, Andalas University, West Sumatera, Indonesia; ${ }^{3}$ Faculty \\ of Pharmacy, Andalas University, West Sumatera, Indonesia
}

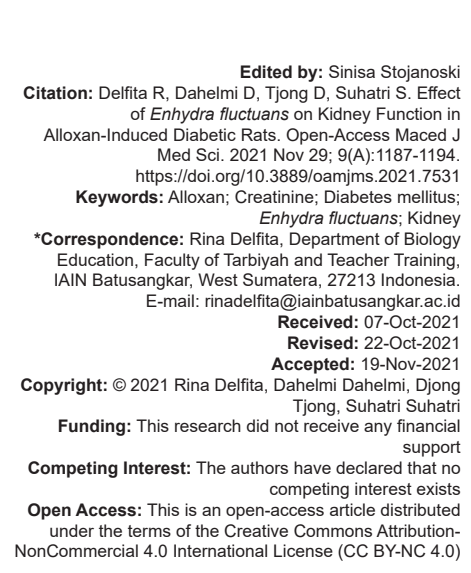

\section{Introduction}

Diabetic nephropathy (DN) is a frequent chronic microvascular consequence of type 2 diabetes mellitus (type $2 \mathrm{DM}$ ) caused by prolonged hyperglycemia [1]. It is believed that this condition affects $20-40 \%$ of diabetes patients [2], [3] and is the leading cause of end-stage renal failure, which is also a leading cause of mortality and disability among type 2 diabetes patients [3]. This long-term hyperglycemia is related to kidney structural abnormalities such as glomerular basement membrane thickening, mesangial enlargement, extracellular matrix deposition, and tubular hypertrophy [4]. Kidney structural abnormalities result in kidney function issues [5]. Therefore, impaired kidney function is a sign of DN [6].

Long-term hyperglycemia causes kidney dysfunction due to the development and circulation of advanced glycation end products, overproduction of pro-inflammatory mediators, and hemodynamic and hormonal disorders [7]. As a result, reactive oxygen species (ROS) and pro-inflammatory cytokines are released. Furthermore, when combined, these alterations cause glomerular hyperfiltration (abnormal glomerular filtration rate [GFR]), glomerular hypertension, renal atrophy, and abnormal glomerular composition, which commonly manifest as albuminuria and high blood pressure [2], [8]. GFR is a key measure of kidney function, and creatinine is used to quantify GFR [9], [10], and a rise in blood urea nitrogen (BUN) is a sign of uremia [3]. As a logical consequence, diabetics require strict blood glucose management.

Several treatments, including oral antihyperglycemic drugs, insulin, and antireninangiotensin system inhibitors, are currently available to prevent and manage this DN. However, the effectiveness of these medications is insufficient [2]. GFR and oxidative status have been reported to be normalized by insulin, thereby delaying the start and progression of chronic kidney disease [6] and elevated blood pressure [11]. Other diabetes medications, such as metformin and insulin secretagogues, may fail to achieve their glycemic goals and prevent diabetic complications such as DN [12]. As a result, the biochemical role of natural resources such as medicinal plants for the prevention or protection against diabetic 
complications has increased attention [13]. In addition, one of the medicinal plants known to have antidiabetic activity is Enhydra fluctuans.

E. fluctuans (Asteraceae) is known as buffalo spinach (UK) and helencha (India) [14]. In West Sumatra, Indonesia, this plant is known as cikarau and used by the community to treat various illnesses such as fever, measles, and others [15]; it is also consumed as a vegetable. The constituents reported in this plant are flavonoid saponins, phenols, tannins, terpenes, and steroids compounds [14]. In addition, this herb is known to have broad biological activities such as hepatoprotective [16], antioxidants [17], and antidiabetic [18], [19]. However, information on the effect of this plant on kidney function in diabetic rats is not known. Therefore, this study aimed to evaluate the effect of $E$. fluctuans aerial on kidney function in alloxan-induced diabetic rats. The rats tested had severe diabetes.

\section{Materials and Methods}

\section{Fractionation of aerial parts of E. fluctuans}

Aerial parts of $E$. fluctuans were collected directly from an abandoned resident's pond, located in Jorong Tabek, Lima Kaum Sub-District, Tanah Datar District, West Sumatra, Indonesia. This plant was validated by plant taxonomists at Andalas University's Department of Biology's Herbarium in Padang, Indonesia (No: 046/ K-ID/ANDA/I/2021). The aerial parts of $E$. fluctuans are dried for up to 15 days until being grounded and screened. Then, using the maceration method, $532 \mathrm{~g}$ of aerial powder were extracted using a $96 \%$ distillate solvent of ethanol. At $40^{\circ} \mathrm{C}$, the extract was evaporated and concentrated using a rotary evaporator (Hei-VAP Core, Germany). Ethanol concentrated extract obtained $123.257 \mathrm{~g}$. The reason for choosing the maceration method is that the procedures and equipment used are simple and not heated, hence, natural ingredients do not become biodegradable. Furthermore, the reason for selecting percent ethanol is that $96 \%$ ethanol is able to dissolve polar and non-polar compounds well and not toxic and volatile, hence, it is suitable for extracting solvents.

In addition, $100 \mathrm{~g}$ of crude extract was dissolved in $96 \%$ ethanol. After dissolving the viscous extract, fractionation was performed using a stratified liquidliquid method with $\mathrm{n}$-hexane as a solvent. Afterward, the fractions were concentrated and stored before being used in the experiment. The n-hexane fraction obtained was $22.811 \mathrm{~g}$. Extraction and fractionation were performed at the Natural Materials Chemistry Laboratory, Department of Chemistry, Andalas University, Padang, Indonesia.

\section{treatment}

Hyperglycemia induction for diabetic

Before induction, Wistar rats $180-250 \mathrm{~g}$ were acclimatized for 3 days and then fasted for $15 \mathrm{~h}$ without food but with a continuous water supply. Furthermore, rats were injected with a $0.9 \% \mathrm{NaCl}$ solution of alloxan at a dose of $125 \mathrm{mg} / \mathrm{kg}$. Diabetes rats were confirmed by measuring blood glucose $96 \mathrm{~h}$ after injection. The rats utilized in this investigation had blood glucose levels of more than $300 \mathrm{mg} / \mathrm{dL}$.

\section{Design of an experimental study}

Diabetic rats were designated to one of five groups $(n=5)$ at random:

$$
\begin{aligned}
& \text { - } \quad \text { Negative control (G0): Diabetic rats }+0.5 \% \\
& \text { Na-CMC } \\
& \text { Positive control (G1): Diabetic rats + } 0.45 \mathrm{mg} / \mathrm{kg} \\
& \text { glibenclamide } \\
& \text { Dose } 1 \text { (G2): Diabetic rats + } 57.03 \mathrm{mg} / \mathrm{kg} \\
& \text { n-hexane fraction of aerial parts of } E \text {. fluctuans } \\
& \text { Dose } 2 \text { (G3): Diabetic rats + } 114.06 \mathrm{mg} / \mathrm{kg} \\
& \text { n-hexane fraction of aerial parts of } E \text {. fluctuans } \\
& \text { Dose } 3 \text { (G4): Diabetic rats + } 171.09 \mathrm{mg} / \mathrm{kg} \\
& \text { n-hexane fraction of aerial parts of E. fluctuans. }
\end{aligned}
$$

The n-hexane fraction of aerial parts of E. fluctuans was chosen because it showed the best antidiabetic activity compared with the ethyl acetate and n-butanol fractions in the preliminary study (data not shown). Therefore, the preliminary study determined the dose (data not shown). Glibenclamide and $\mathrm{n}$-hexane fraction were dissolved in $0.5 \% \mathrm{Na}-\mathrm{CMC}$ and taken orally once daily for 21 days. Rats had unlimited access to food and water. The kidney function testing of diabetic rats was conducted at Balai Veteriner Laboratory, Bukittinggi, West Sumatra, Indonesia.

\section{Blood glucose measurement}

Fasting blood samples were collected directly from the rats' tails on days $0-21$. Furthermore, a glucometer (Gluco Dr. Auto ${ }^{\mathrm{TM}}$, Model AGM-4000, Korea) was used to measure blood glucose levels.

\section{Kidney tissue sampling}

The kidney was isolated at the end of the experiment from each group. Rats were anesthetized with ether, then dissected and carefully removed their kidneys. The kidneys were fixed with $10 \%$ buffer neutral formalin (BNF) before being processed for histopathological examination. The samples were fixed in paraffin, sectioned at a thickness of $5 \mu \mathrm{m}$, and stained with hematoxylin and eosin (H\&E), and images were taken by photo microscope (Olympus DP 22, Tokyo, Japan). Kidney preparations were observed with an objective magnification of $400 \times$ and in five different fields 
of view with at least 10 glomerular tissues and 10 tubular tissues (distal and proximal tubules) for each field of view.

\section{Kidney damage score}

Khalid's technique [20] was used to calculate the kidney damage score. Glomerular damage is scored 0 if no damage occurs, 1 if Bowman's capsules thicken, 2 if glomerular tuft retraction occurs, and 3 if glomerular fibrosis develops. Tubular damage is scored as follows: 0 if there is no damage, 1 if $<25 \%$ of tubular cells are lacking brush border, 2 if weight loss is greater than $25 \%$ of tubular cells, and thicker basement membrane. Score 3 when there is inflammation, cast formation, and necrosis of up to $60 \%$ of tubular cells, and 4 if necrosis occurs in more than $60 \%$ of tubular cells. Subsequently, two people read the preparations to obtain reliability and validity. Finally, the percentage of kidney damage for each treatment was calculated [21].

\section{Biochemical test}

Biochemical test was seen from BUN and creatinine levels. Furthermore, a test kit (DiaSys ${ }^{\mathrm{TM}}$, Germany) was used to determine BUN and creatinine levels. The test kit is used in accordance with the instructions provided by the manufacturer, and the results are displayed in $\mathrm{mg} / \mathrm{dL}$. BUN and creatinine testing were conducted out in the Biochemistry Laboratory, Faculty of Medicine, Andalas University, Padang, Indonesia.

\section{Preliminary phytochemical analysis}

Phytochemical studies were performed on the n-hexane fraction of $E$. fluctuans aerial, and the study examined for alkaloids, flavonoids, saponins, terpenoids, steroids, phenolics, and coumarin. Furthermore, the testing was conducted qualitatively using standard techniques [22]. Phytochemical screening was conducted at the Natural Materials Chemistry Laboratory, Department of Chemistry, Andalas University, Padang, Indonesia.

\section{Data statistical analysis}

Data for five rats in each experimental group are presented as mean standard error. SPSS 21 was used for statistical analysis. The hypothesis was then proven correct using one-way ANOVA. Duncan's new multiple range test was used if the significant difference $(p<0.05)$ was confirmed. Data on kidney cell damage were descriptively statistically analyzed and presented in the following percentage.

$\%$ reduction of blood glucose $=\left(1-\frac{W_{e}}{W_{c}}\right) \times 100$
Where, $W_{e}$ is the blood glucose levels in the glibenclamide or fraction administration and $W_{c}$ is the level of blood glucose in control administration [23].

\section{Ethical approval}

The handling of rats was established under guidelines by the Study Ethics Committee of Faculty of Medicine, Andalas University, Padang, Indonesia (No: 038/KEP/FK/2019).

\section{Results}

\section{reduction}

\section{Blood glucose level and blood glucose}

Figure 1 shows the effect of n-hexane fraction of aerial parts of $E$. fluctuans on blood glucose levels and the percentage of blood glucose decrease in diabetic rats after 21 days of treatment. On day 0 , the average blood glucose level in normal animals was $73.20 \pm 3.70 \mathrm{mg} / \mathrm{dL}$, while the blood glucose of alloxan-induced diabetic rats averaged $387.60 \pm 25.79-479.00 \pm 43.75 \mathrm{mg} / \mathrm{dL}(5-6$ times blood glucose levels of normal rats). After 21 days of treatment, the blood glucose of normal rats was relatively constant $(75.00 \pm 8.86 \mathrm{mg} / \mathrm{dL})$, whereas blood glucose

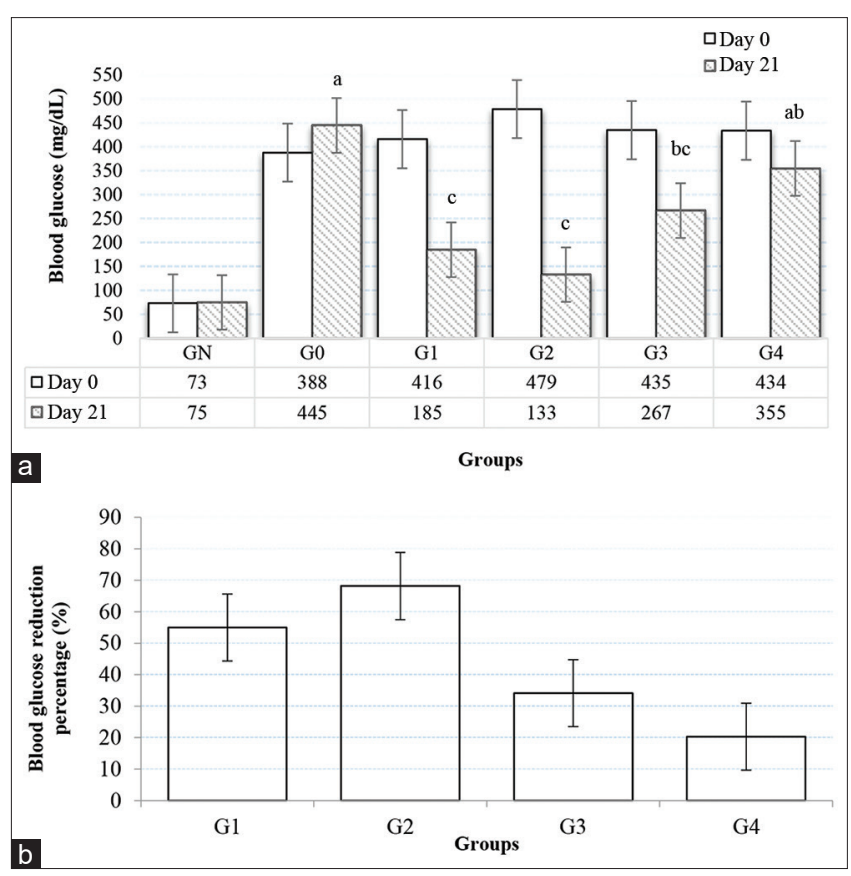

Figure 1: The effect of $n$-hexane fraction of aerial parts of $E$. fluctuans on blood glucose levels and the percentage of blood glucose decrease in diabetic rats after 21 days of treatments. (a) Blood glucose level and (b) percentage reduction in blood glucose. GN. Normal rats; G0. Negative control; G1. Positive control; G2. Dose of $57.03 \mathrm{mg} / \mathrm{kg}$; G3. Dose of $114.06 \mathrm{mg} / \mathrm{kg}$; and G4. Dose of $171.09 \mathrm{mg} / \mathrm{kg}$. The different letters indexes $(a, b, c)$ above each bar chart indicate significant difference dependent on Duncan's new multiple range test $(p<0.05)$ versus negative control 
was high in diabetic rats and varied depending on the treatment. Thus, administration of $n$-hexane fraction of aerial parts of $E$. fluctuans for 21 days effectively lowers the blood glucose of diabetic rats. The treatment dose of $57.03 \mathrm{mg} / \mathrm{kg}$ (G2) showed the lowest blood glucose and was significantly different $(p<0.05)$ compared with the control $(\mathrm{G} 0)$, but remained comparable with glibenclamide ( $\mathrm{G} 1 ; \mathrm{p}>0.05)$. The percentage of blood glucose decreased in $\mathrm{G} 2$ is also the highest (Figure $1 \mathrm{~b}$ ). It suggests that the n-hexane fraction of aerial parts of $E$. fluctuans exerted an antidiabetic activity with an equal activity as glibenclamide (G1), particularly at a dose G2.

\section{Histopathological findings}

Figure 2 shows the effect of $n$-hexane fraction of aerial parts of $E$. fluctuans on the kidney histopathology of diabetic rats. Furthermore, the glomerulus, proximal tubules, and distal tubules of rat kidneys exhibit normal histological features, as shown in Figure 2a. It shows the glomerulus appears to have a normal-sized nucleus, a capsular space, and a thin capsular membrane. The proximal tubule seems normal, with an irregular cell shape and a brush border and the nucleus appears to be less abundant than the distal tubule. It also shows that the distal tubule is smaller and has more nuclei in the tubular membrane than the proximal tubule.

Diabetic rats' kidneys were negatively affected (Figure 2b). The constriction of the glomerular space and inflammation of the glomerulus are symptoms of kidney disease. The proximal tubule lost $60 \%$ of

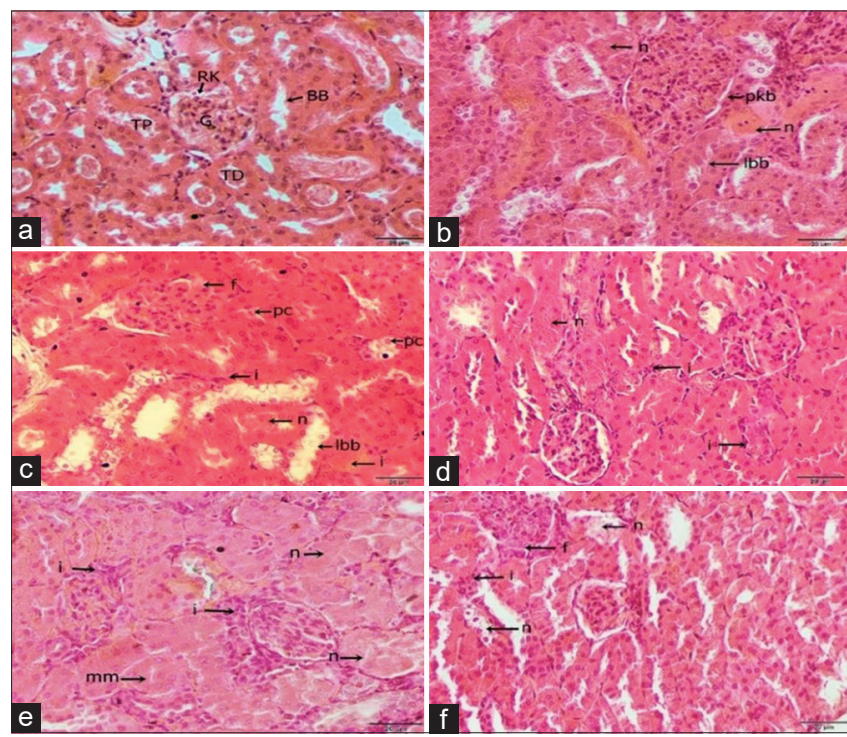

Figure 2: Effect of n-hexane fraction of aerial parts of $E$. fluctuans on kidney histology of diabetic rats. (a) Normal rats (GN), (b) negative control (G0), (c) positive control (G1), (d) dose of $57.03 \mathrm{mg} / \mathrm{kg}$ (G2), (e) dose of $114.06 \mathrm{mg} / \mathrm{kg}$ (G3), (f) dose of $171.09 \mathrm{mg} / \mathrm{kg}$ (G4), and (g) glomerulus, RK. Bowman's capsule space, TP. Proximal tubule, TD. Distal tubule, BB. Brush borders, f. Glomerular fibrosis, pkb. Bowman's capsule thickening, n. Tubular necrosis, $\mathrm{mm}$. Thickened tubular basement membrane, i. Tubular inflammation, Ibb. Lost/ increased brush border, and pc. Tubular cast/gips formation its bush borders, and a significant amount of tubular tissue was necrotic. In the basement membrane, the distal tubule becomes thickened. There were many glomerular fibrosis, tubular cast formation, and inflammation in diabetic rats administered glibenclamide (Figure 2c). The n-hexane fraction resulted in numerous healthy glomeruli, less tubular tissue necrosis, and inflammation in rats. Treatment with n-hexane fraction substantially reduced these damages in diabetic rats' renal tissue (Figure 2d-f). These positive benefits of $E$. fluctuans appear related to improved oxidative stress, decreased inflammatory responses, and decreased apoptotic rate in renal cells. These data imply that E. fluctuans is a natural agent capable of alleviating some of the pathogenic processes implicated in DN.

\section{Kidney damage score}

Figure 3 describes the effect of the n-hexane fraction of aerial parts of $E$. fluctuans on the percentage of glomerular and tubular damage in diabetic rats. Figure 3 a shows the categories of glomerular damage in diabetic rats, which are fibrosis, tuft retraction, and
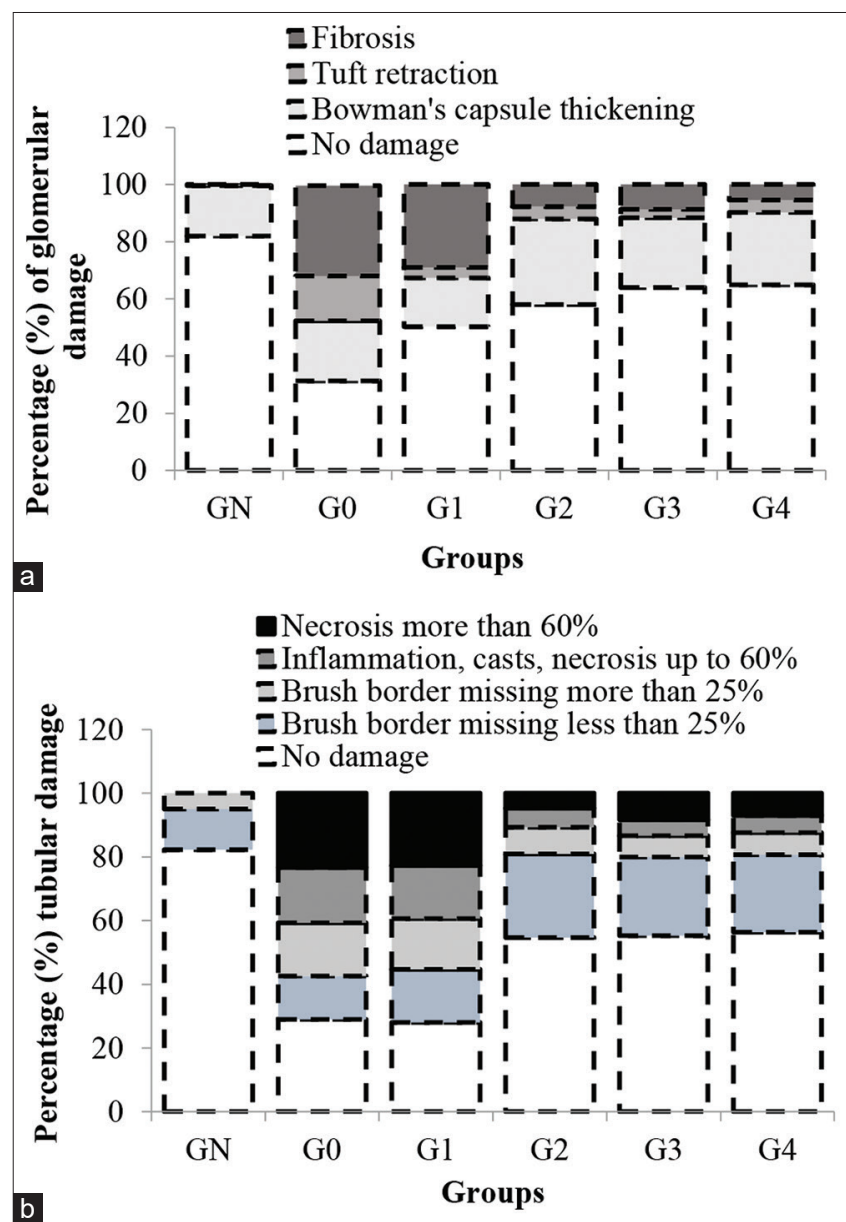

Figure 3: Effect of administration of $n$-hexane fraction of $E$. fluctuans on the percentage of kidney damage in diabetic rats. GN. Normal rats; G0. Negative control; G1. Positive control; G2. Dose of $57.03 \mathrm{mg} / \mathrm{kg} . \mathrm{bb}$; G3. Dose of $114.06 \mathrm{mg} / \mathrm{kg} . \mathrm{bb}$; and G4. Dose of $171.09 \mathrm{mg} / \mathrm{kg} . \mathrm{bb} . A=$ Glomerulus and $B=$ Tubules 
thickening of Bowman's capsule. The percentage of glomerular damage is different depending on the treatment. Furthermore, the percentage of normal (undamaged) glomerulus was high in G4 followed by G3 and G2 (65, 64, and 58\%, respectively), while in $\mathrm{G} 0$ and $\mathrm{G} 1$, it was 31.33 and $50.33 \%$, respectively. The highest fibrosis was discovered in G0 (31.67\%) followed by $\mathrm{G} 1(29 \%)$, while in $\mathrm{G} 2, \mathrm{G} 3$, and $\mathrm{G} 4$, it was $7.67,8.67$, and $5.33 \%$, respectively. The highest tuft retraction was discovered in G0 (15.67\%) and the lowest in G3 (3\%), while Bowman's capsule thickening was highest in G2 $(30 \%)$ and the lowest in G1 (17\%). Thus, it is known that the percentage of glomerular damage in diabetic rats given the n-hexane fraction ( $\mathrm{G} 2, \mathrm{G} 3$, and $\mathrm{G} 4$ ) is lower than the percentage of glomerular damage in G0 and G1. Furthermore, G4 treatment showed the lowest percentage of glomerular damage compared with G2 and G3 treatments. This low percentage of glomerular damage shows that $E$. fluctuans protect the renal glomerulus from damage due to high blood glucose toxicity.

In Figure 3b, the categories of tubular damage in diabetic rats are loss of brush border loss of $<25 \%$, loss of brush border loss of more than $25 \%$ and thickening of the basement membrane, inflammation, formation of casts, and necrosis up to $60 \%$, and necrosis more than $60 \%$. Tubular necrosis was high in G0 (23.33\%) and G1 (22.67\%). Tubular necrosis at G2, G3, and G4 was 4.67, 8.33, and $7.00 \%$, respectively. The highest percentage of tubular inflammation was in G0 (17.33\%), and the lowest was in G3 (5.00\%). Loss of brush border and basement membrane thickening was highest in G2 (16.67\%) and the lowest in G3 (6.67\%). The highest percentage of brush border loss of $<25 \%$ was in treatment G2 (26.33\%), and the lowest was in G0 (13.67\%). However, the highest percentage of normal tubules (56.33\%) was discovered in G4 followed by G3 $(55.33 \%)$ and G2 (54.67\%). The percentage of tubular damage in treatments G2, G3, and G4 was almost the same. Thus, the percentage of tubular damage in diabetic rats treated with n-hexane fraction of aerial parts of $E$. fluctuans was lower when compared with $\mathrm{G} 0$ and $\mathrm{G} 1$ treatments. This low percentage of tubular damage shows that $E$. fluctuans had activity to protect the kidney tubules from damage due to high blood glucose toxicity. The result of the percentage calculation of kidney damage was supported by the BUN and creatinine (Table 1).

Table 1: Effect of the $n$-hexane fraction of aerial parts of E. fluctuans on BUN and creatinine levels of diabetic rats after 21 days of treatment

\begin{tabular}{lll}
\hline Groups & Kidney function \\
\cline { 2 - 3 } & BUN $(\mathrm{mg} / \mathrm{dL})$ & Creatinine $(\mathrm{mg} / \mathrm{dL})$ \\
\hline Normal group (GN) & $22.38 \pm 1.64$ & $0.69 \pm 0.13$ \\
Negative control group (G0) & $41.00 \pm 1.81^{\mathrm{a}}$ & $1.38 \pm 0.10^{\mathrm{a}}$ \\
Positive control group (G1) & $34.48 \pm 3.73^{\mathrm{ab}}$ & $1.12 \pm 0.13^{\mathrm{a}}$ \\
Dose $57.03 \mathrm{mg} / \mathrm{kg}$ of $\mathrm{n}$-hexane fraction (G2) & $21.84 \pm 1.67^{\mathrm{c}}$ & $0.75 \pm 0.07^{\mathrm{b}}$ \\
Dose $114.06 \mathrm{mg} / \mathrm{kg}$ of $\mathrm{n}$-hexane fraction (G3) & $24.60 \pm 1.89^{\mathrm{c}}$ & $0.70 \pm 0.07^{\mathrm{b}}$ \\
Dose $171.09 \mathrm{mg} / \mathrm{kg}$ of n-hexane fraction (G4) & $28.00 \pm 2.00^{\mathrm{bc}}$ & $0.76 \pm 0.13^{\mathrm{b}}$ \\
\hline Data were expressed as Mean $\pm \mathrm{SE}$. The one-way ANOVA followed by Duncan's New Multiple Range \\
Test. The different letter indexes (a, b, c) in the same column indicate significantly different $p<0.05$ versus \\
negative control
\end{tabular}

\section{Biochemical Test (BUN and creatinine)}

The effect of the $n$-hexane fraction of aerial parts of $E$. fluctuans on the BUN and creatinine levels in diabetic rats is shown in Table 1. BUN and creatinine levels in diabetic rats are high, but the administration of the n-hexane fraction of aerial parts of $E$. fluctuans lowers BUN and creatinine to the normal level. BUN and creatinine levels in G2, G3, and G4 treatments were significantly different $(p<0.05)$ when compared with negative control (G0) and glibenclamide (G1), but BUN and creatinine levels in G2, G3, and G4 were not significantly different $(p>0.05)$ between treatments. The lowest BUN level was discovered at G2 $(21.84 \pm 1.67 \mathrm{mg} / \mathrm{dL})$, and the lowest creatinine level was at G3 $(0.70 \pm 0.07 \mathrm{mg} / \mathrm{dL})$. Thus, BUN and creatinine levels that returned to normal show that the n-hexane fraction of aerial parts of $E$. fluctuans has protective activity and repairs damage to kidney function. The low BUN and creatinine are also supported by histology data and the low percentage of damage to the kidney (Figures 2 and 3). Therefore, these results show a renoprotective effect of aerial parts of $E$. fluctuans.

\section{Preliminary phytochemical analysis of the n-hexane fraction}

The preliminary phytochemical investigation of the $\mathrm{n}$-hexane fraction of $E$. fluctuans aerial showed that they contain terpenoids and steroids.

\section{Discussion}

The effect of $n$-hexane fraction of aerial parts of $E$. fluctuans on diabetic rats' renal function is investigated in this study. Furthermore, alloxaninduced diabetic rats experienced histological changes such as increased fibrosis, glomerular hypertrophy, glomerular space narrowing, loss of tubules brush border, and necrotic and thickened basal membranes increased BUN and creatinine, which decreased kidney function and induced DN. On the contrary, all treatments of n-hexane fraction of aerial E. fluctuans enhanced kidney histological structure while lowering BUN and creatinine (Table 1). Thus, E. fluctuans is known to enhance hyperglycemic rats' renal function. These positive benefits are linked to a lower oxidative stress, a lower inflammatory response, and a lower apoptotic rates in kidney cells. These findings suggest E. fluctuans as a natural agent that ameliorates several pathogenic processes involved in DN.

Under conditions of hyperglycemia, overproduction of free radicals and/or impaired antioxidant defense mechanisms caused oxidative stress [24]. As essential oxidants, free radicals are created through various chemical pathways, but 
the majority of these free radicals are produced by the action of the enzyme NADPH oxidase [25]. Sadeek et al. [26] stated that the overexpression of NOX-4 by hyperglycemia is a significant source of free radicals in renal tissue, stimulating redox-sensitive signaling pathways implicated in ROS generation. NOX-4 inhibition by siRNA or GKT-136901 (NOX-specific inhibitor) substantially reduced glucose-induced $\mathrm{O} 2$ and $\mathrm{H} 2 \mathrm{O} 2$ generation [26], [27].

In diabetic kidneys, free radicals such as lipid peroxide and nitric oxide are generated in excess, while antioxidant enzymes such as GSH-Px are reduced, resulting in oxidative stress and inflammation [28]. The major cause of DN caused by oxidative stress. Oxidative stress causes glomerular thickening, basement membrane expansion, mesangial cell growth, glomerular hypertrophy and podocyte loss, expansion of tubular basement membrane, tubular atrophy, fibrosis, and arteriosclerosis [29]. Abdullah et al. [30] stated that chronic oxidative stress in diabetics causes kidney damage, which raises BUN and creatinine levels. According to Samra and Abcar [31], a rise in BUN and creatinine levels caused reducing the average GFR due to glomerular injury.

One of the most promising treatment methods is the administration of antioxidants. Although the antioxidant activity of the n-hexane fraction of aerial parts of E. fluctuans was not measured in this study, this activity was seen from the lower percentage of kidney damage than the control. This study proved the antioxidants' positive benefits, such as the group of terpenoid and steroid compounds contained in the $n$-hexane fraction of $E$. fluctuans aerial. Exogenous antioxidants and compounds such as terpenoids and steroids have reduced free radicals in diabetic rats [32]. Terpenoids are known to have strong antioxidant activity [33]. These compounds inhibited the formation of free radicals and the production of inflammatory mediators [34]. E. fluctuans has a high level of antioxidant activity [35], [36]. This herb increased redox parameters while inhibiting lipid oxidation, proteins carbonylation, and intrinsically and extrinsically apoptotic indicators are all implicated in the overall protective impact [17].

Hasan et al. [19] investigated the effect of E. fluctuans ethanol extract on creatinine levels. Their findings revealed that administering an ethanol extract of pre-diabetic rats did not affect their creatinine levels. Meanwhile, this study discovered that administration of the n-hexane fraction of aerial parts of $E$. fluctuans affected BUN and creatinine levels in diabetic rats (Table 1). These findings suggest that administration of aerial parts of $E$. fluctuans improves kidney structure and function of diabetic rats, thereby increasing the GFR of diabetic rats. The increase in GFR in the kidneys will result in urea excretion, and creatinine also increases, hence, the levels of urea and creatinine in the blood decrease. However, the effect of the n-hexane fraction of aerial parts $E$. fluctuans on BUN and creatinine levels on severe diabetic rats has been reported for the $1^{\text {st }}$ time.

In summary, the findings show that n-hexane fraction of aerial parts of $E$. fluctuans is beneficial in reducing blood glucose and avoiding fibrosis, glomerular hypertrophy, glomerular space narrowing tubular loss of brush border, necrosis, and basal membrane thickening. All doses showed the same activity to improve kidney function. As a result, the findings of this investigation suggest that n-hexane fraction of aerial parts of $E$. fluctuans improves kidney function in severely diabetic rats. However, further study is needed to discover how E. fluctuans antioxidant activity protects the kidneys against hyperglycemic toxicity.

\section{Conclusion}

This study revealed that the administration of the n-hexane fraction of $E$. fluctuans aerial improved the kidney function of diabetic rats. As a result, E. fluctuans was used to prevent the development of diabetes mellitus and DN.

\section{Acknowledgments}

The authors are grateful to the Head of Faculty of Tarbiyah and Teacher Training (FTIK) IAIN Batusangkar, West Sumatera, Indonesia, for the facilities provided in conducting this study.

\section{References}

1. Uddandrao VV, Brahmanaidu $P$, Ravindarnaik $R$, Suresh $P$ Vadivukkarasi S, Saravanan G. Restorative potentiality of S-allyl cysteine against diabetic nephropathy through attenuation of oxidative stress and inflammation in streptozotocin-nicotinamideinduced diabetic rats. Eur J Nutr. 2019;58(6):2425-37. https:// doi.org/10.1007/s00394-018-1795-x

PMid:30062492

2. Umanath $\mathrm{K}$, Lewis JB. Update on diabetic nephropathy: Core curriculum 2018. Am J Kidney Dis. 2018;71(6):884-95. https:// doi.org/10.1053/j.ajkd.2017.10.026

PMid:29398179

3. Bhatia K, Misra P, Singh A, Mukherjee B, Ambade VN. Study of blood urea nitrogen (BUN), serum creatinine in diabetic and nondiabetic patients in a Tertiary Care Hospital. Int J Med Biomed Stud. 2019;3(4):180-6. https://doi.org/10.32553/ijmbs.v3i4.216

4. Fujita H, Fujishima H, Chida S, Takahashi K, Qi Z, Kanetsuna Y. Reduction of renal superoxide dismutase in progressive diabetic 
nephropathy. J Am Soc Nephrol. 2009;20(6):1303-13. https:// doi.org/10.1681/asn.2008080844

PMid:19470681

5. Gansevoort RT, Correa-Rotter R, Hemmelgarn BR, Jafar TH, Heerspink HJ, Mann JF. Chronic kidney disease and cardiovascular risk: Epidemiology, mechanisms, and prevention. Lancet. 2013;382(9889):339-52. https://doi.org/10.1016/ S0140-6736(13)60595-4

PMid:23727170

6. Gross JL, Azevedo MJ, Silveiro SP, Canani LH, Caramori ML, Zelmanovitz T. Diabetic nephropathy: Diagnosis, prevention, and treatment. Diabetes Care. 2005;28(1):176-88. https://doi. org/10.2337/diacare.28.1.164

PMid:15616252

7. Yaribeygi $H$, Mohammadi MT, Rezaee R, Sahebkar A. Crocin improves renal function by declining Nox-4, IL-18, and p53 expression levels in an experimental model of diabetic nephropathy. J Cell Biochem. 2018;119(7):6080-93. https://doi. org/10.1002/jcb.26806

PMid:29575259

8. Papachristoforou E, Lambadiari V, Maratou E, Makrilakis K. Association of glycemic indices (hyperglycemia, glucose variability, and hypoglycemia) with oxidative stress and diabetic complications. J Diabetes Res. 2020;2020:7489795. https://doi. org/10.1155/2020/7489795

PMid:33123598

9. Travlos GS, Morris RW, Elwell MR, Duke A, Rosenblum S, Thompson MB. Frequency and relationships of clinical chemistry and liver and kidney histopathology findings in 13-week toxicity studies in rats. Toxicology. 1996;107(1):17-29. https://doi. org/10.1016/0300-483X(95)03197-N

PMid:8597028

10. Nwankpa P, Ekweogu C, Egwurugwu, JN, Chukwuemeka O, Etteh C, Ugwuezumba $\mathrm{P}$, et al. Assessment of kidney function indices in male albino Wistar rats administered ethanol stem extract of Dennettia tripetala (Pepper fruit). Biochem Pharmacol Open Access. 2018;7(1):1-4. https://doi. org/10.4172/2167-0501.1000242

11. Herman ME, O'Keefe JH, Bell DS, Schwartz SS. Insulin therapy increases cardiovascular risk in Type 2 diabetes. Prog Cardiovasc Dis. 2017;60(3):422-34. https://doi.org/10.1016/j. pcad.2017.09.001 PMid:28958751

12. Xu S, Wang B, Liu W, Wu C, Huang J. The effects of insulin therapy on mortality in diabetic patients undergoing percutaneous coronary intervention. Ann Transl Med. 2021;9(16):1294. https:// doi.org/10.21037/atm-21-1911

PMid:34532431

13. Vasarri M, Barletta E, Vinci S, Ramazzotti M, Francesconi A, Manetti F. Annona cherimola miller fruit as a promising candidate against diabetic complications: An in vitro study and preliminary clinical results. Foods. 2020;9(10):1350. https://doi. org/10.3390/foods 9101350

PMid:32987622

14. Ali R, Billah M, Hassan M, Rahman SM. Enhydra fluctuans Lour : A review. Res J Pharm Tech. 2013;6(9):927-9. https://doi. org/10.11114/ijsss.v4i5.1522

15. Stark A, Yahaya FH, Kurniawan Y. Tawa nan ampek: A traditional way of healing measles, keteguran and other disorders in West Sumatra. Int J Soc Sci Stud. 2016;4(5):90-4. https://doi. org/10.11114/ijsss.v4i5.1522

16. Kumar SP, Jagannath PV, Chandra DS, Prasan ND. Hepatoprotective activity of Enhydra fluctuans Lour. Aerial parts against $\mathrm{CCl} 4$ induced hepatotoxicity in rats. Int J Res Ayurveda Pharm. 2012;3(6):893-6. https://doi. org/10.7897/2277-4343.03646
17. DuaTK,DewanjeeS,KhanraR, JoardarS, BarmaS.Cytoprotective and antioxidant Effects of an edible herb, Enhydra fluctuans Lour. (Asteraceae), against experimentally induced lead acetate intoxication. PLoS One. 2016;11(2):e0148757. https://doi. org/10.1371/journal.pone.0148757

PMid:26859407

18. Delfita R, Tjong DH, Dahelmi D, Suhatri S. Hypoglycemic effects of Enhydra fluctuans aerial extract on alloxan-induced diabetic rats. J Phys Conf Ser. 2021;1940(1):1-7. https://doi. org/10.1088/1742-6596/1940/1/012058

19. Hasan MN, Sabrin F, Rokeya B, Khan MS, Ahmed MU, Matondo A. Glucose and lipid-lowering effects of Enhydra fluctuans extract in cadmium treated normal and Type-2 diabetic model rats. BMC Complement Altern Med. 2019;19(1):278. https://doi. org/10.1186/s12906-019-2667-5

PMid:31640743

20. Khalid U. Kidney ischaemia reperfusion injury in the rat: The EGTI scoring system as a valid and reliable tool for histological assessment. J Histol Histopathol. 2016;3(1):2-7. https://doi. org/10.7243/2055-091X-3-1

21. Zhao B, Wu F, Han X, Zhou W, Shi Q, Wang H. Protective effects of acarbose against insulitis in multiple low-dose streptozotocininduced diabetic mice. Life Sci. 2020;263:118490. https://doi. org/10.1016/j.lfs.2020.118490

PMid:32979357

22. Putra IB, Jusuf NK, Sumantri IB. The potency of Hibiscus rosa- sinensis Linn. leaves ethanol extract as hair growth. Open Access Maced J Med Sci. 2020;8(A):89-92. https://doi.org/10.3889/oamjms.2020.4211

23. Saha M, Rohani S, Rayhana N, Toma IJ, Rana S, Rahmatullah M. An herbal formulation containing Zingiber officinale rhizomes and Allium sativum cloves can increase oral glucose tolerance in mice. Biol Eng Med. 2017;2(1):1-3. https://doi.org/10.15761/ BEM. 1000110

24. Giacco F, Brownlee M. Oxidative stress and diabetic complications. Circ Res. 2010;107(9):1058-70. https://doi. org/10.1161/circresaha.110.223545

PMid:21030723

25. Lotfy M, Adeghate J, Kalasz H, Singh J, Adeghate E. Chronic complications of diabetes mellitus: A mini-review. Curr Diabetes Rev. 2016;13(1):3-10. https://doi.org/10.2174/15733998126661 51016101622

PMid:26472574

26. Sedeek M, Callera G, Montezano A, Gutsol A, Heitz F, Szyndralewiez C. Critical role of Nox4-based NADPH oxidase in glucose-induced oxidative stress in the kidney: Implications in Type 2 diabetic nephropathy. Am J Physiol Renal Physiol. 2010;299(6):1348-59. https://doi.org/10.1152/ ajprenal.00028.2010

PMid:20630933

27. Liang $Y$, Liu H, Fang Y, Lin P, Lu Z, Zhang P. Salvianolate ameliorates oxidative stress and podocyte injury through modulation of NOX4 activity in DB/DB mice. J Cell Mol Med. 2020;25(2):1012-23. https://doi.org/10.1111/jcmm.16165 PMid:33332718

28. Wang L, Zhang L, Yu Y, Wang Y, Niu N. The protective effects of taurine against early renal injury in STZ-induced diabetic rats, correlated with inhibition of renal LOX-1-mediated ICAM-1 expression. Ren Fail. 2008;30(8):763-71. https://doi. org/10.1080/08860220802272563

PMid: 18791949

29. Forbes JM, Coughlan MT, Cooper ME. Oxidative stress is a major culprit in kidney disease in diabetes. Diabetes. 2008;57(6):1446-54. https://doi.org/10.2337/db08-0057 PMid: 18511445 
30. Abdullah KM, Alam MM, Iqbal Z, Naseem I. Therapeutic effect of vitamin B3 on hyperglycemia, oxidative stress and DNA damage in the alloxan-induced diabetic rat model. Biomed Pharmacother. 2018;105(6):1223-31. https://doi.org/10.1016/j. biopha.2018.06.085

PMid:30021358

31. Samra M, Abcar AC. False estimates of elevated creatinine. Perm J. 2012;16(2):51-2. https://doi.org/10.7812/tpp/11-121 PMid:22745616

32. Gonzalez-Burgos E, Gomez-Serranillos MP. Terpene compounds in nature: A review of their potential antioxidant activity. Curr Med Chem. 2012;19(31):5319-41. https://doi. org/10.2174/092986712803833335

PMid:22963623

33. Abou El-Soud NH, El-Lithy NA, El-Saeed G, Wahby MS,
Khalil MY, Morsy F, et al. Renoprotective effects of Caraway (Carum carvi L.) essential oil in streptozotocin-induced diabetic rats. J Appl Pharm Sci. 2014;4(2):27-33.

34. Mabhida SE, Dludla PV, Johnson R, Ndlovu M, Louw J, Opoku AR. Protective effect of triterpenes against diabetesinduced $\beta$-cell damage: An overview of in vitro and in vivo studies. Pharmacol Res. 2018;137:179-92. https://doi. org/10.1016/j.phrs.2018.10.004 PMid:30315968

35. Sarkar P, Dalal A. Evaluation of antioxidant activity of Diplazium esculentum and Enhydra fluctuans of West Bengal. IOSR J Pharm Biol Sci. 2016;11(6):45-50.

36. Panigrahi R, Bhatnagar S. Cytotoxic, the phytochemical and antioxidant potential of marshy herb Enhydra fluctuans Lour. Int J Ethnobiol Ethnomed. 2015;1:1-5. 